\title{
Effect of exercise on protein turnover in muscles of lean and obese mice
}

\author{
G. Augert, S. Monier and Y. Le Marchand-Brustel \\ Unité de Recherches sur les Hormones Polypeptidiques et la Physiopathologie Endocrinienne, Institut National de la Santé \\ et de la Recherche Médicale, INSERM U 145, Faculté de Médecine (Pasteur), Nice, France
}

\begin{abstract}
Summary. The effect of work-induced hypertrophy on skeletal muscle protein metabolism was studied in lean mice and in mice rendered obese with goldthioglucose. After tenotomy of the gastrocnemius muscle, the adaptative growth of soleus muscle was less pronounced in obese than in lean mice. Protein turnover was studied in the isolated soleus muscle 4 days after the operation. Tyrosine incorporation in total proteins and tyrosine release in the incubation medium (indices of protein synthesis and degradation) were increased by 3 - and 2 -fold in overloaded (i.e. work-induced hypertrophied) muscles of lean and obese mice, respectively, compared to the control muscles isolated from the non-operated leg. The qualitative modifications in the pattern of proteins synthetized
\end{abstract}

from ${ }^{35} \mathrm{~S}$-methionine were identical in both groups of mice. This increase in protein turnover in overloaded muscles results from an increased rate of polypeptide chain initiation (3-fold in lean mice, 2.2-fold in obese mice) without any modification of peptide chain elongation rates. Work-induced hypertrophy was also able to reverse the defect in amino acid uptake which is present in soleus muscles of GTG-obese mice. These results suggest that the work-induced increase of skeletal muscle protein turnover is diminished in obese mice.

Key words: Obesity, protein synthesis, soleus muscles, workinduced hypertrophy.
Obesity is mainly characterized by an excess lipid deposition, hyperinsulinaemia and a decrease in lean body mass [1-4]. In genetically obese mice, this decrease in muscular mass has been attributed to an increase in protein degradation [1] or to a defect in protein synthesis [5]. In a previous study performed in mice rendered obese with goldthioglucose (GTG), we could not detect any alteration in protein turnover measured in two isolated muscles (soleus and extensor digitorum longus), and we suggested that the abnormalities observed in obese animals in vivo could be the consequence of a complex abnormal hormonal profile or/and of reduced physical activity $[6,7]$. Indeed, contractile activity appears to be a fundamental determinant of muscle mass, and can even take precedence over endocrine signals [8]. In order to study the effect of exercise on muscular protein metabolism in obese mice, we have used the following approach: by cutting the tendon of the gastrocnemius muscle, an important work load is applied to the soleus muscle of the same leg $[9,10]$. In the present paper, we have thus compared an overloaded, hypertrophied muscle in one leg to a control muscle in the other leg within a same animal. We have shown that the effect of work-induced hypertrophy is less important in obese mice than in lean controls for protein synthesis, but is similar in both groups of mice for amino acid uptake.

\section{Materials and methods}

\section{Materials}

Radioactive products were purchased from the Radiochemical Centre, Amersham England, or from New England Nuclear, Dreieich, FRG. Pactamycin was a gift from the Upjohn Co, Kalamazoo, MI, USA. All other reagents were of the best grade commercially available, and were obtained from Sigma, St. Louis, MO, USA; Merck, Darmstadt, FRG; or Boehringer, Mannheim, FRG. All reagents for SDS-gel electrophoresis were from Bio-Rad Laboratories, Richmond, CA, USA.

\footnotetext{
Animals

Male Swiss Albino mice were provided laboratory chow (Usine d'Alimentation Rationnelle, Villemoisson, Epinay-Sur-Orge, France) ad libitum and maintained at $23{ }^{\circ} \mathrm{C}$ on a 12 -h light cycle until the time of killing. Mice were rendered obese by goldthioglucose (GTG) injection at 3 weeks of age [11] and used when obesity had reached a plateau, i. e. between 20 and 30 weeks of age. Age-matched lean animals were used as controls.
} 
Table 1. Characteristics of animals and of soleus muscles

\begin{tabular}{|c|c|c|c|}
\hline & Lean & $\begin{array}{l}\text { Goldthioglucose } \\
\text { (GTG)-obese }\end{array}$ & $p$ \\
\hline Body wt. (g) & $\begin{array}{l}45.1 \pm 0.7 \\
(12)\end{array}$ & $\begin{array}{l}66.3 \pm 2.3 \\
(12)\end{array}$ & $<0.005$ \\
\hline $\begin{array}{l}\text { Plasma glucose } \\
(\mathrm{mmol} / 1)\end{array}$ & $\begin{array}{l}9.6 \pm 0.4 \\
(12)\end{array}$ & $\begin{array}{l}10.9 \pm 0.4 \\
(12)\end{array}$ & $<0.05$ \\
\hline $\begin{array}{l}\text { Insulinaemia } \\
(\mathrm{nmol} / \mathrm{l})\end{array}$ & $\begin{array}{r}0.5 \pm 0.1 \\
(12)\end{array}$ & $\begin{array}{r}8.3 \pm 1.9 \\
(12)\end{array}$ & $<0.005$ \\
\hline \multicolumn{4}{|c|}{ Soleus muscle wet weight (mg) } \\
\hline Control & $\begin{array}{l}9.6 \pm 0.5 \\
(7)\end{array}$ & $\begin{array}{c}10.1 \pm 0.3 \\
(9)\end{array}$ & NS \\
\hline Overloaded & $\begin{array}{r}14.5 \pm 0.5 \\
(7)\end{array}$ & $\begin{array}{r}15.3 \pm 0.9 \\
(9)\end{array}$ & NS \\
\hline$\Delta$ & $\begin{array}{l}4.9 \pm 0.4 \\
(7)\end{array}$ & $\begin{array}{l}5.2 \pm 0.5 \\
(9)\end{array}$ & NS \\
\hline \multicolumn{4}{|c|}{ Soleus muscle protein (mg/muscle) } \\
\hline Control & $\begin{array}{l}1.87 \pm 0.05 \\
(17)\end{array}$ & $\begin{array}{l}1.92 \pm 0.06 \\
(15)\end{array}$ & NS \\
\hline Overloaded & $\begin{array}{l}2.19 \pm 0.06 \\
(17)\end{array}$ & $\begin{array}{l}2.09 \pm 0.07 \\
(15)\end{array}$ & NS \\
\hline$\Delta$ & $\begin{array}{l}0.32 \pm 0.04 \\
(17)\end{array}$ & $\begin{array}{l}0.17 \pm 0.02 \\
(15)\end{array}$ & $<0.005$ \\
\hline
\end{tabular}

Muscle wet weight and protein contents were measured after removal of tendons. $\Delta$ represents the change in the soleus muscle wet weight or protein content induced by tenotomy of the gastrocnemius muscle within each animal. Values are expressed as mean \pm SEM with the number of values given in parentheses. Statistical significance between lean and obese mice is indicated

\section{Surgical procedures}

Under ether anaesthesia, the distal tendon of the gastrocnemius muscle of one leg was dissected free from the tendon of the soleus muscle. As much tendon as possible was removed to prevent tendon reapproximation by fibrosis as described in the rat $[9,10]$. Muscles of the unoperated contralateral legs were used as controls, since there was no difference between muscles from sham-operated or from non-operated legs [12, data not shown]. Four days after the operation (when the hypertrophy reached a plateau [13]), mice were killed by cervical dislocation and soleus muscles were isolated and incubated as previously described [11] in $1 \mathrm{ml}$ Krebs-Ringer bicarbonate buffer ( $\mathrm{pH} 7.3$ ) containing pyruvate $(2 \mathrm{mmol} / \mathrm{l})$. The additions were specified in each experiment. All incubations were preceeded by a 15 -min pre-incubation period.

\section{Measurement of protein synthesis and protein degradation}

The rates of protein synthesis, estimated by ${ }^{3} \mathrm{H}$-tyrosine incorporation in trichloracetic acid precipitable material, were measured as previously described $[6,14,15]$. Muscles were incubated at $37^{\circ} \mathrm{C}$ in the medium described above supplemented with branch chain amino acids (leucine $0.2 \mathrm{mmol} / 1$, isoleucine $0.1 \mathrm{mmol} / 1$, valine $0.2 \mathrm{mmol} / \mathrm{l}$ ) and $\mathrm{L}$ (side chain $\left.2,3-{ }^{3} \mathrm{H}\right)$ tyrosine $(0.1 \mathrm{mmol} / 1,1 \mu \mathrm{Ci} / \mathrm{ml}, 16 \mathrm{Ci} / \mathrm{mmol}$ and $\left({ }^{4} \mathrm{C}\right)$-inulin $(1.25 \mu \mathrm{Ci} / \mathrm{ml} ; 400 \mathrm{mCi} / \mathrm{mmol})$. At the end of the 3 - $\mathrm{h}$ incubation, muscles were freeze-clamped and homogenized; trichloroacetic acid-precipitable proteins were then measured. Aliquots of supernatant following trichloroacetic acid precipitation were used for tyrosine assay, and for determination of ${ }^{14} \mathrm{C}$ and ${ }^{3} \mathrm{H}$ radioactivity. In each muscle, the intracellular specific radioactivity of tyrosine was calculated [6, 14]; overload did not affect intracellular specific activity of tyrosine (data not shown). Protein degradation was estimated by measuring tyrosine released in the incubation medium in the presence of cycloheximide $(0.5 \mathrm{mmol} / 1)$ to block protein synthesis $[6,14,15]$. In the latter case, cycloheximide was also present during the pre-incubation period.

\section{Determination of polypeptide chain initiation rate}

Muscles were incubated for 3 to $26 \mathrm{~min}$ with pactamycin $[16,17]$ $(2 \mu \mathrm{mol} / \mathrm{l})$ and $\left({ }^{14} \mathrm{C}\right)$-leucine $(0.66 \mu \mathrm{Ci} / \mathrm{ml} ; 300 \mathrm{mCi} / \mathrm{mmol})$. At the end of incubation, muscles were freeze-clamped and sonicated in ice cold potassium phosphate buffer $(10 \mathrm{mmol} / 1, \mathrm{pH} 7.3)$ containing $1 \mathrm{mmol} / \mathrm{l}$ phenylmethylsulfonyl fluoride. Homogenates were centrifuged for $10 \mathrm{~min}$ at $8000 \mathrm{~g}$. Labelled proteins present in the supernatant which represented nascent polypeptide chains were determined [7].

\section{Polyacrylamide gel electrophoresis (PAGE)}

Muscles were incubated for $3 \mathrm{~h}$ with $\left({ }^{35} \mathrm{~S}\right)$-methionine $(50 \mu \mathrm{Ci} / \mathrm{ml}$, $1000 \mathrm{Ci} / \mathrm{mmol}$ ) in the medium described above. Muscles were then lysed by sonication in a boiling SDS solution (3\% SDS wt/vol, $10 \%$ glycerol vol/vol), and the samples were treated at $100{ }^{\circ} \mathrm{C}$ for $5 \mathrm{~min}$ after addition of 2 -mercaptoethanol $(2 \% \mathrm{vol} / \mathrm{vol})$ and bromophenol blue $(0.01 \%$, wt $/ \mathrm{vol})$. Proteins contained in SDS extracts were analysed by one-dimensional gel electrophoresis [18] using a 5-15\% linear gradient of acrylamide as a resolving gel and a 3\% stacking gel. The gels were stained with Coomassie blue $(0.25 \%$ solution in $50 \%$ (wt $/ \mathrm{vol})$ trichloracetic acid) destained in $7 \%(\mathrm{vol} / \mathrm{vol})$ acetic acid, vacuum dried and exposed to Kodak X-omat films. The proteins used as molecular weight markers were: Myosin heavy chain (200000) $\beta$ galactosidase (116000) phosphorylase B ( 94000$)$ bovine serum albumin (67000) ovalbumin (43000) carbonic anhydrase (30000) soybean trypsin inhibitor (20000) and lysozyme (14000). ${ }^{35} \mathrm{~S}$-methionine incorporation into TCA-precipitable proteins was also measured.

\section{Amino acid uptake}

Following a 2-h pre-incubation, muscles were incubated for $30 \mathrm{~min}$ at $37^{\circ} \mathrm{C}$ in buffer containing a mixture of $\left({ }^{14} \mathrm{C}\right)$ aminoisobutyric acid (AIB) $(0.2 \mu \mathrm{Ci} / \mathrm{ml}, 0.1 \mathrm{mmol} / 1)$ and ${ }^{3} \mathrm{H}$-inulin $(1 \mu \mathrm{Ci} / \mathrm{ml})$. Amino acid uptake was linear for this incubation duration [19]. At the end of incubation muscles were treated and counted [19].

\section{Statistical analysis}

Results, expressed per mg of muscle protein [20] or per whole muscle, are presented as the means \pm SEM for the number of individual muscles indicated in the legends to figures. Statistical significance was assessed using the paired Student's t-test, with the overloaded muscle and the contralateral non-operated muscle from the same animal being compared. When muscles from different animals were used, Student's t-test for unpaired comparisons was used [21].

\section{Results}

\section{Effect of work-induced hypertrophy on protein synthesis and degradation in soleus muscles}

The characteristics of the mice used in this study are shown in Table 1. Mice injected with goldthioglucose were obese, slightly hyperglycaemic and markedly hyperinsulinaemic, and thus were insulin-resistant. Four days after tenotomizing the gastrocnemius muscle, work-induced hypertrophy of the soleus muscle was 

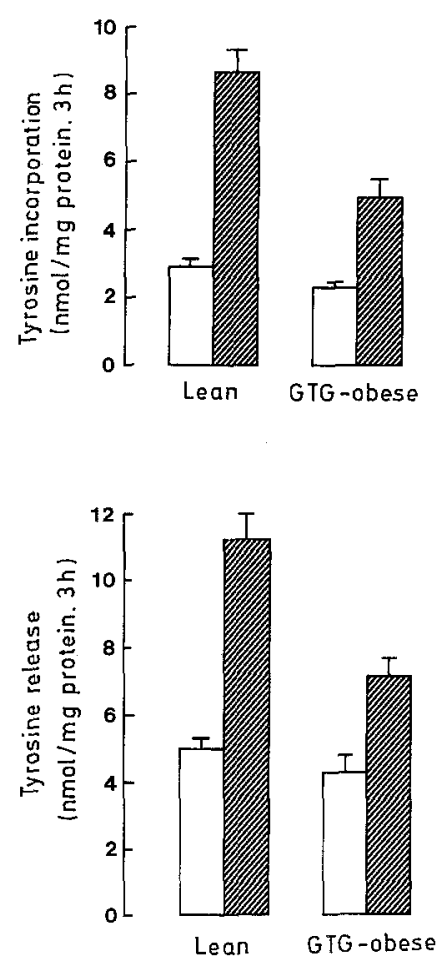

Fig. 1. Effect of work-induced hypertrophy on protein synthesis and protein degradation in soleus muscles of lean and goldthioglucose obese mice. Upper panel: Control or overloaded (work-induced hypertrophied) soleus muscles from the same mouse were incubated for $3 \mathrm{~h}$ in Krebs-Ringer bicarbonate buffer containing $2 \mathrm{mg} / \mathrm{ml}$ defatted bovine albumin, pyruvate $(2 \mathrm{mmol} / \mathrm{l})$, branch chain amino acids, and $\left({ }^{3} \mathrm{H}\right)$-tyrosine $(0.1 \mathrm{mmol} / \mathrm{l})$. Tyrosine incorporation in TCA-precipitable proteins was measured. Lower panel: Muscles were incubated for $3 \mathrm{~h}$ in the same medium without amino acids and in the presence of cycloheximide $(0.5 \mathrm{mmol} / \mathrm{l})$; protein degradation was estimated from the amount of released tyrosine in the medium. Results are means \pm SEM of 4-12 muscles. $\square$ Control, 国overloaded

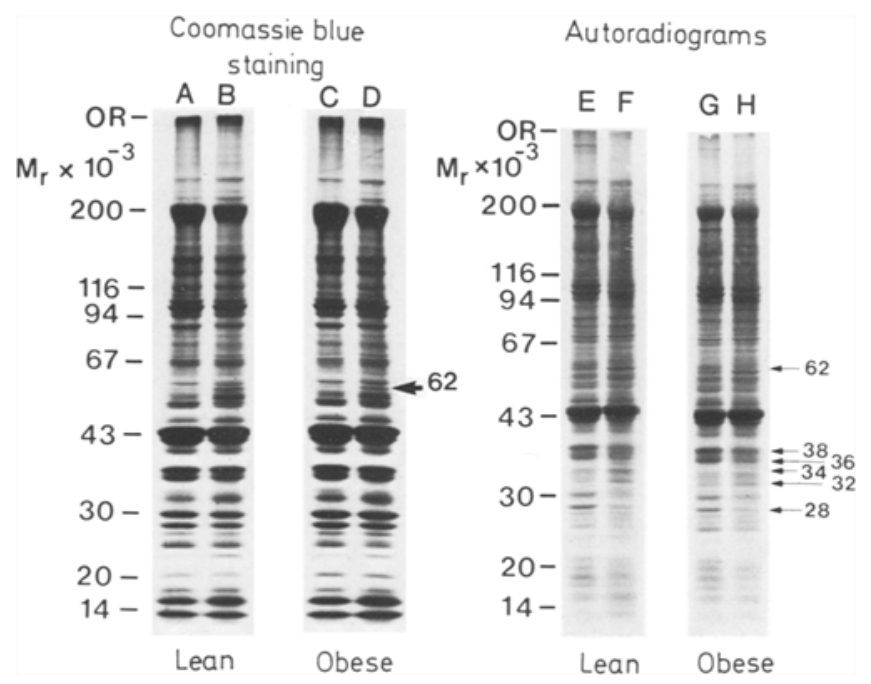

Fig. 2. Polyacrylamide gel electrophoresis of proteins of overloaded and control soleus muscles of lean and goldthioglucose obese mice. Muscles were incubated for $3 \mathrm{~h}$ with ${ }^{35} \mathrm{~S}$-methionine and lysed in boiling SDS; samples were analyzed by one-dimensional gel electrophoresis. Coomassie blue staining of total proteins and autoradiograms of ${ }^{35} \mathrm{~S}$-labeled proteins (the same amount of radioactivity was loaded in each lane) are presented. Control muscles are in lanes A, C, E and G, overloaded muscles in lanes B, D, F, H
Table 2. Effect of work-induced hypertrophy on protein synthesis from methionine in soleus muscles of lean and goldthioglucose obese mice.

\begin{tabular}{llll}
\hline Muscle & \multicolumn{4}{l}{$\begin{array}{l}\text { Methionine incorporation into proteins } \\
\mathrm{cpm} \times 10^{-6} / 3 \mathrm{~h} \text { and } / \text { muscle }\end{array}$} \\
\cline { 2 - 4 } & Lean & GTG-obese & $p$ \\
\hline Control & $3.41 \pm 0.19$ & $3.42 \pm 0.17$ & $\mathrm{NS}$ \\
Overloaded & $6.50 \pm 0.22$ & $5.44 \pm 0.38$ & $<0.05$ \\
\hline
\end{tabular}

Muscles were incubated for $3 \mathrm{~h}$ with ${ }^{35} \mathrm{~S}$-methionine $(50 \mu \mathrm{Ci} / \mathrm{muscle})$. At the end of incubation, proteins were precipitated and counted. Each value is the mean \pm SEM of 3-4 different muscles

maximal [13]. Since oedema occurs in hypertrophied muscles [13, 22], muscle growth was measured as the accumulation of protein rather than as changes in muscle wet weight. As shown in Table 1, tenotomy of the gastrocnemius muscle induced a $17.1 \%$ and a $8.9 \%$ increase in muscle protein content in lean and GTG-obese mice, respectively (the difference between lean and obese mice being highly significant, $p<0.005$ ). In order to explain this difference between the two types of mice, changes in protein synthesis and protein breakdown were studied in isolated soleus muscles. As shown in Figure 1, (upper panel) tyrosine incorporation was increased 3.2-fold in overloaded muscles of lean mice compared to controls. In muscles of GTG-obese mice, work-induced hypertrophy induced only a 2-fold increase. As previously reported in control muscles, basal rates of protein synthesis were not different between lean and GTG-obese mice [6]. Tyrosine release into the medium (Fig. 1, lower panel) an index of protein breakdown, was also found to be significantly increased by 2.5 -fold and 1.7-fold in overloaded muscles of lean and GTG-obese mice respectively. Results have been expressed per mg muscle protein, but the effect of hypertrophy would be unchanged if results were expressed per muscle.

Total muscular proteins and newly synthetized proteins from labelled methionine were then analyzed by SDS-polyacrylamide gel electrophoresis. Coomassie blue staining (Fig. 2, left panel) revealed few differences in the protein bands between overloaded and control muscles except for the appearance of a 62000 band. More differences between control and overloaded muscles appeared in the pattern of labeled proteins synthetized from ${ }^{35} \mathrm{~S}$-methionine during a 3-h incubation. Methionine incorporation into total proteins was markedly increased in overloaded muscles compared to controls (Table 2). As observed with tyrosine (Fig. 1) the effect of work-induced hypertrophy on methionine incorporation into total TCA-precipitable proteins was less pronounced in obese than in lean mice (Table 2). To facilitate the qualitative comparisons between the different conditions, the autoradiograms shown in Figure 2, right panel, were obtained from gels in which the same amount of radioactivity was loaded in each lane. Some bands were more heavily labelled (for example, 62000 , 


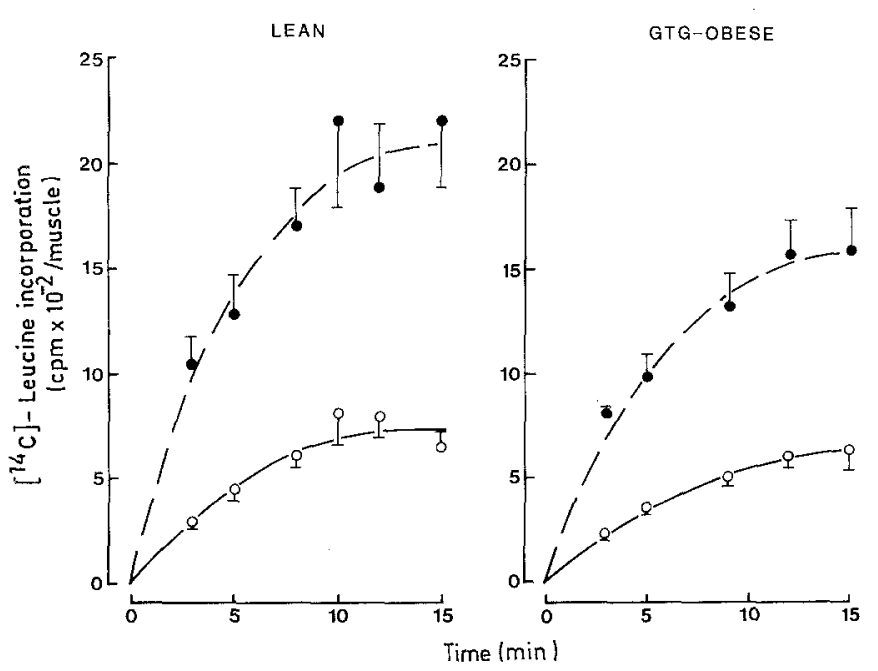

Fig. 3. Effect of work-induced hypertrophy on the initiation rate of polypeptide chains in soleus muscles of lean and goldthioglucose obese mice. Muscles were incubated for 3 to $15 \mathrm{~min}$ in Krebs-Ringer bicarbonate buffer containing $\left({ }^{14} \mathrm{C}\right)$-leucine $(0.66 \mu \mathrm{Ci} / \mathrm{ml})$ and pactamycin $(2 \mu \mathrm{mol} / 1)$. Muscle homogenates were centrifuged for $10 \mathrm{~min}$ at $8000 \mathrm{~g}$ and $\left({ }^{14} \mathrm{C}\right)$-leucine incorporation in TCA-precipitable proteins of $8000 \mathrm{~g}$ supernatants (nascent polypeptide chains) were determined. O Control, Overloaded

Table 3. Effect of work-induced hypertrophy on aminoisobutyric acid uptake in soleus muscles of lean and goldthioglucose obese mice.

\begin{tabular}{llll}
\hline Muscle & \multicolumn{3}{l}{$\begin{array}{l}\text { Aminoisobutyric acid uptake nmol } / \mathrm{mg} \\
\text { protein.30 min }\end{array}$} \\
\cline { 2 - 4 } & Lean & GTG-obese & $p$ \\
\hline Control & $0.51 \pm 0.03$ & $0.29 \pm 0.02$ & $<0.05$ \\
Overloaded & $0.97 \pm 0.09$ & $0.88 \pm 0.07$ & $\mathrm{NS}$ \\
\hline
\end{tabular}

Soleus muscles isolated from lean or goldthioglucose obese mice were preincubated for $2 \mathrm{~h}$ in Krebs-Ringer bicarbonate buffer containing $10 \mathrm{mg} / \mathrm{ml}$ bovine albumin. Muscles were then incubated in the same medium supplemented with $\left({ }^{14} \mathrm{C}\right)$-aminoisobutyric acid $(0.1 \mathrm{mmol} / \mathrm{l}$, $0.2 \mu \mathrm{Ci} / \mathrm{ml}$ and $\left({ }^{3} \mathrm{H}\right)$-inulin $(1 \mu \mathrm{Ci} / \mathrm{ml})$ for $30 \mathrm{~min}$. At the end of incubation, muscles were washed and treated. Each value is the mean \pm SEM of 4-6 different muscles

32-34000) while the labelling of other bands (for example, $64000,38000,36000,30000,28000$ ) was faint in hypertrophied muscle. More importantly, these changes induced by hypertrophy were similar in muscles from lean and GTG-obese mice.

\section{Effect of work-induced hypertrophy on peptide chain initiation and elongation}

It has been generally found that stimulation of protein synthesis by insulin $[7,23]$ or by increasing heart work load [24] occurs at the level of the rate of initiation of polypeptide chains. We therefore looked for an effect of work-induced hypertrophy on initiation step in soleus muscles. Muscles were incubated with pactamycin, a drug which specifically blocks initiation of new peptide chains without preventing elongation of the chains al- ready initiated before the addition of the drug $[16,17]$. As shown in Figure 3, work-induced hypertrophy markedly increased polypeptide chain initiation. Thus, the amount of radioactivity present in nascent polypeptide chains after pactamycin addition was increased by 3 -fold and 2.2-fold in overloaded muscles of lean and GTG-obese mice respectively.

In contrast, when the ribosomal transit times for proteins (an index of elongation step) were determined as previously described [7], the values were not modified by work-induced hypertrophy $\left(\mathrm{t}_{1 / 2}=0.41 \pm 0.06 \mathrm{~min}\right.$ and $0.46 \pm 0.16$ in control and hypertrophied muscle of lean mice, respectively, mean \pm SEM of 4 different experiments).

\section{Effect of work-induced hypertrophy on amino acid transport}

An alteration of aminoisobutyric (AIB) uptake has previously been described in muscles of obese mice [19]. We thus studied the effect of work-induced hypertrophy on the uptake of AIB in soleus muscles of both lean and obese mice. As shown in Table 3, AIB uptake was decreased in control muscles of GTG-obese mice compared to control muscles of lean mice. Work-induced hypertrophy was able to reverse this defect, with values obtained in overloaded muscles being similar in lean and obese mice.

\section{Discussion}

Following tenotomy of the gastrocnemius muscle, the soleus muscle undergoes a rapid compensatory hypertrophy both in lean and obese animals [13], with passive stretch being the main factor involved in inducing the rapid growth of the overloaded muscle $[12,26]$. However, as reported in this study, this adaptive growth is less pronounced in obese mice than in their lean controls. Indeed, while protein turnover was increased about 3 times in lean animals, only a doubling was observed in obese mice, and the net increase in protein content was lower in hypertrophied muscles of obese than in lean mice. In contrast, qualitative changes of the proteins induced by tenotomy were similar in obese and in lean mice; for example, tenotomy markedly increased the content of a protein with $\mathrm{Mr} 62000$ (as reported in the rat [25]) and modified the pattern of low molecular weight proteins. These results suggest that tenotomy of the gastrocnemius muscle induces important modifications of the proteins in the soleus [26], but that differences in the response of obese mice are only quantitative and not qualitative. It is possible that those changes in the pattern of labelled proteins represent an internal remodelling of the tissue [26].

In all models studied thus far, skeletal muscle hypertrophy is accompanied by an acceleration of protein turnover [12, 26] and an increase in AIB uptake [27]. The 
reason why protein degradation is stimulated together with protein synthesis is not clear, but it can be observed that in the large majority of reports of altered muscle growth, protein synthesis and degradation rose and fell in concert $[26,28]$. In the present study with isolated soleus muscles, as in all systems of isolated muscles $[6,12$, $14,15]$, protein balance is negative, i.e. degradation is higher than synthesis. Many technical difficulties are associated with the measurement of protein turnover rates in vitro [29]. The absolute rates of protein turnover measured in vitro in isolated systems are markedly different from those observable in vivo, and thus the results presented in this paper could be questioned on technical grounds. However, recent studies [12] have clearly shown that in vivo and in vitro methods of measuring protein synthesis and degradation are in good agreement concerning the changes in protein turnover induced by tenotomy of the gastrocnemius. The in vivo techniques could not be used in lean and obese mice due to the tiny size of soleus muscles in those animals.

The effect of work-induced hypertrophy on tyrosine incorporation into proteins seems to be due to an increased rate of peptide chain initiation. Neither tyrosine uptake, which is mediated through the $L$ aminoacid transport system, nor protein elongation rate are modified by work-induced hypertrophy. The degree of stimulation of protein synthesis is closely related to the degree of stimulation of peptide chain initiation (Fig. 3). Our results are in agreement with the model of Bergmann and Lodish [30], in which the stimulation of protein synthesis can be correlated to that of initiation rate without modification of elongation rate. Such a correlation between protein synthesis and initiation rates was found for the effects induced by insulin or insulin-like growth factor [7, 31]. Increased initiation rates can also result in part from an increase in mRNA levels in hypertrophied muscles.

This study has also shown that the defect in AIB uptake already reported [19] in muscles of obese mice is suppressed by work-induced hypertrophy (Table 3 ). These results are parallel to the results obtained for 2-deoxyglucose uptake, since the alteration in basal and insulin-stimulated glucose transport was reversed in overloaded muscles of obese mice [13]. The complete normalization of aminoacid uptake, together with a lower effect of tenotomy on protein turnover in obese mice, suggests that the work applied to the soleus muscles by tenotomy of the gastrocnemius muscle was very similar in lean and obese mice. It also confirms that none of the A system amino acids appear to be rate-limiting for protein synthesis [29].

Acknowledgments. We are greatly indebted to G.Visciano, T.Gremeaux and N. Grenier-Brossette for technical help and illustration work, to J.Duch, L. Capolongo and A. Rainaud for excellent secretarial assistance. This work was supported by grant MIR $83 \mathrm{C} 0447$ and by research funds from INSERM, and from the University of Nice (France).

\section{References}

1. Trostler N, Romsos DR, Bergen WG, Leveille GA (1979) Skeletal muscle accretion and turnover in lean and obese $(o b / o b)$ mice. Metabolism 28: 928-933

2. Shapira JF, Kircher I, Martin RJ (1980) Indices of skeletal muscle growth in lean and obese Zucker rats. J Nutr 110: 1313-1318

3. Lin PY, Romsos DR, Leveille GA (1977) Food intake, body weight gain, and body composition of the young obese (ob/ob) mouse. J Nutr 107: 1715-1723

4. Bergen WG, Kaplan ML, Merkel RA, Leveille GA (1975) Growth of adipose and lean tissue mass in hindlimbs of genetically obese mice during preobese and obese phases of development. Am J Clin Nutr 28: 157-161

5. Shargill NS, Ohshima K, Bray GA, Chan TM (1984) Muscle protein turnover in the perfused hindquarters of lean and genetically obese-diabetic $(d b / d b)$ mice. Diabetes 33: 1160-1164

6. Monier S, Le Cam A, Le Marchand-Brustel Y (1983) Insulin and insulin-like growth factor I: effects on protein synthesis in isolated muscles from lean and goldthioglucose-obese mice. Diabetes 32: 392-397

7. Monier S, Le Marchand-Brustel Y (1982) Insulin affects only initiation and not elongation in protein synthesis in soleus muscles of lean and obese mice. FEBS Lett. 147: 211-214

8. Goldberg AL (1979) Influence of insulin and contractile activity on muscle size and protein balance. Diabetes 28 (Suppl 1): 18-24

9. Goldberg AL (1967) Work-induced growth of skeletal muscle in normal and hypophysectomized rats. Am J Physiol 213: $1193-1198$

10. Goldberg AL, Etlinger JD，Goldspink DF，Jablecki C (1975) Mechanism of work-induced hypertrophy of skeletal muscle. Med Sci Sports 7: 248-261

11. Le Marchand-Brustel Y, Jeanrenaud B, Freychet P (1978) Insulin binding and effects in isolated soleus muscles of lean and obese mice. Am J Physiol 234: E348-E358

12. Goldspink DF, Garlick PJ, McNurlan MA (1983) Protein turnover measured in vivo and in vitro in muscles undergoing compensatory growth and subsequent denervation atrophy. Biochem J 210: 89-98

13. Augert G, Van de Werve G, Le Marchand-Brustel Y (1985) Effect of work-induced hypertrophy on muscle glucose metabolism in lean and obese mice. Diabetologia 28: 295-301

14. Fulks RM, Li JB, Goldberg AL (1975) Effects of insulin, glucose, and amino acids on protein turnover in rat diaphragm. $\mathrm{J}$ Biol Chem 250: 290-298

15. Frayn KN, Maycock PF (1979) Regulation of protein metabolism by a physiological concentration of insulin in mouse soleus and extensor digitorum longus muscles. Effects of starvation and scald injury. Biochem J 184: 323-330

16. Scott WA, Shields R, Tomkins GM (1972) Mechanism of hormonal induction of tyrosine amino transferase studied by measurement of the concentration of growing enzyme molecules. Proc Natl Acad Sci USA 69: 2937-2941

17. Snoek GT, Van de Poll KW, Voorma HO, Van Wijk R (1981) Studies of the posttranscriptional site of cAMP action in the regulation of the synthesis of tyrosine aminotransferase. Eur J Biochem 114: $27-31$

18. Laemmli UK (1970) Cleavage of structural proteins during the assembly of the head of bacteriophage T4. Nature 227: 680-685

19. Le Marchand-Brustel Y, Moutard N, Freychet P (1982) Aminoisobutyric acid transport in soleus muscles of lean and goldthioglucose-obese mice. Am J Physiol 243: E74-E79

20. Lowry OH, Rosebrough NJ, Farr AL, Randall RJ (1951) Protein measurement with the Folin phenol reagent. J Biol Chem 193: $265-275$

21. Snedecor GW, Cochran WG (1967) Statisticals methods, 6th edn. Iowa State University Press, Ames

22. Armstrong RB, Marum P, Tullson P, Saubert CW IV (1979) Acute hypertrophic response of skeletal muscle to removal of synergists. J Appl Physiol Respir Environ Exercise Physiol 46: 835-842 
23. Wool IG, Castles JJ, Leader DP, Fox A (1972) Insulin and the function of muscle ribosomes. In: Steiner DF, Freinkel N (eds) Handbook of physiology, Sect 7. Endocrinology, vol. 1. Physiological Society, Washington DC, pp 385-394

24. Hjalmarson A, Isaksson $\mathrm{O}$ (1972) In vitro work load and rat heart metabolism. III. Effect on ribosomal aggregation. Acta Physiol Scand 86: 342-352

25. Yamada S, Tomino S, Izumi S, Akino M (1984) Purification, molecular properties and biosynthesis of a specific protein component induced under compensatory hypertrophy in the rat skeletal muscle. Biochim Biophys Acta 798: 260-267

26. Laurent GJ, Millward DJ (1980) Protein turnover during skeletal muscle hypertrophy. Fed Proc 39: 42-47

27. Goldberg AL, Goodman HM (1969) Amino-acid transport during work-induced growth of skeletal muscle. Am J Physiol 216: 1111-1115

28. Reeds PJ, Palmer RM (1984) Changes in prostaglandin release associated with inhibition of muscle protein synthesis by dexamethasone. Biochem J 219: 953-957
29. Waterlow JC, Garlick PJ, Millward DJ (1978) Protein turnover in mammalian tissues and in the whole body. North Holland, Amsterdam

30. Bergmann JE, Lodish HF (1979) A kinetic model of protein synthesis. Application to hemoglobin synthesis and translational control. J Biol Chem 254: 11927-11937

31. Monier S, Le Marchand-Brustel Y (1984) Effects of insulin and IGF-I on RNA synthesis in isolated soleus muscle. Mol Cell Endocrinol 37: 109-114

Received: 21 October 1985

and in revised form: 3 February 1986

Dr. Y.Le Marchand-Brustel

INSERM U 145

Faculté de Médecine (Pasteur)

Avenue de Valombrose

F-06034 Nice Cédex

France 